\title{
Læknablaðið í sókn - nýjar leiðbeiningar til höfunda fræðigreina
}

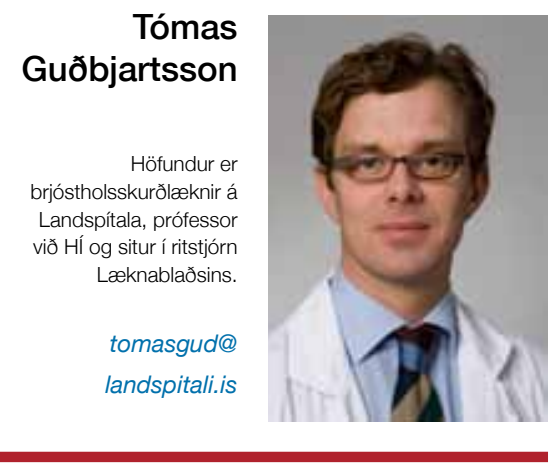

Í pessu tölublaði Læknablaðsins eru birtar nýjar og endurbættar leiðbeiningar fyrir höfunda fræðigreina. ${ }^{1}$ Pær hafa nú verið endurskoðaðar frá grunni og flokkar fræðigreina endurmetnir, sem og viðmið um lengd, fjölda tilvísana og frágang myndefnis og taflna. Vinna við endurbæturnar hefur staðið í tæpt ár. Undirritaður hefur leitt pá vinnu en margir hafa lagt hönd á plóginn, bæði innan og utan ritstjórnar. Markmiðið er að styrkja blaðið í sessi sem alpjóðlegt vísindarit, enda er Læknablaðið nú skráð í helstu gagnagrunna vísindatímarita á sviði lífvísinda. Tekið hefur verið mið af höfundaleiðbeiningum vísindarita eins og New England Journal of Medicine, Lancet, JAMA og British Medical Journal.

\section{Helstu áherslubreytingar}

- Flokkar fræðigreina hafa verið einfaldaðir og lengdartakmarkanir hvers flokks eru nú gefnar upp í fjölda orða í stað slaga áður. Á pað bæði við um ágrip (hámark 250 orð fyrir vísindagreinar) og meginmál greina (hámark 3000 orð fyrir vísindagreinar og 5000 orð fyrir yfirlitsgreinar). Hverjum flokki fylgja ítarlegri leiðbeiningar en áður um efnistök og frágang texta.

- Fjöldi heimilda í hverjum flokki hefur verið endurskoðaður, til dæmis er hann að hámarki 30 í vísindagreinum í stað 25 áđur. Hámarksfjöldi tilvísana er sem fyrr 60 í yfirlitsgreinum á pappír, en í netútgáfu gefst höfundum kostur á birtingu fleiri heimilda.

- Frágangur heimilda er nokkuð breyttur. Greint er frá nöfnum allra höfunda nema peir séu fleiri en sex, pá er bætt aftan við sjötta nafnið et al. Pegar vitnað er í íslenskar vísindagreinar eru nöfn höfunda skrifuð samkvæmt enskri ritvenju. Heiti greinar og Læknablaðsins er pó sem fyrr á íslensku. Vinnustaðar og háskólatengsla skal nú getið bæði á ensku og íslensku. Með pessum breytingum er leitast við að gera leit í alpjóðlegum gagnagrunnum eins og PubMed og Web of Science auðveldari og tryggja að greinin sé tengd réttum háskóladeildum.

- Kröfur til yfirlitsgreina eru auknar. Höfundar verða nú að gera grein fyrir pví hvernig heimildir voru fundnar í rafrænum gagnagrunnum. Einnig er lögð áhersla á að stuðst sé við ritrýndar heimildir.

- Flokkar sjúkratilfella, sem áður voru sjúkratilfelli annars vegar og hins vegar sjúkratilfelli með yfirliti, hafa verið sameinaðir í einn flokk.

- Nýtt og ítarlegra eyðublað er komið í stað tveggja eldri eyðublaða um hagsmunatengsl og höfundayfirlýsingu. Lögð er áhersla á að eyðublaðið berist um leið og greinin er send til blaðsins. Eins og áður verða allir höfundar að afsala sér birtingarrétti til Lxknabladsins og gefa upp hugsanleg hagsmunatengsl. Jafnframt verða allir höfundar að greina frá framlagi sínu til rannsóknarinnar og/eða ritun greinarinnar. Pessar áherslur taka mið af breyttum kröfum erlendra vísindarita.

- Skerpt hefur verið á reglum varðandi tvíbirtingu fræðigreina. Almennt er gerð sú krafa að efnið hafi ekki birst í öðrum vísindaritum. Einstaka undantekningar eru frá pessari meginreglu og er tvíbirting aðeins möguleg í samráði við ritstjórn Læknablaðsins ef sérstakar ástæður pykja fyrir birtingunni. Pá verður að liggja fyrir skriflegt leyfi frá ritstjóra pess blaðs par sem greinin birtist fyrst.

- Öllum fræðigreinum skal fylgja bréf til blaðsins par sem höfundar rökstyðja í stuttu máli af hverju greinin á erindi í
Læknablaðið. Nú verður einnig að geta númera á leyfum og/eða tilkynningum vegna rannsókna, til dæmis frá Vísindasiðanefnd og Persónuvernd.

- Ekki parf lengur að tilgreina lykilorð á íslensku, heldur aðeins á ensku.

- Lögð er mikil áhersla á að samræma útlit myndefnis. Pví eru sýnd dæmi um uppsetningu á töflum og myndum sem æskilegt er að fylgja. Texti við töflur og myndir parf að vera bæði á íslensku og ensku. Senda verður myndir í sérstakri jpg-skrá, ekki í Word-skjali. Heildarfjölda taflna og mynda hefur verið breytt og er hann nú 8 í vísindagreinum og 10 í yfirlitsgreinum.

- Nú er stefnt að pví að höfundar fái ritrýni î hendur innan priggja mánaða frá pví að handrit er sent til blaðsins. Hafi höfundum verið gefinn kostur á pví að lagfæra handritið, með hugsanlega birtingu í huga, er nú miðað við að peir hafi tvo mánuði til pess. Berist leiðrétt handrit ekki innan pess tíma, er litið svo á að höfundar hafi ekki lengur áhuga á birtingu greinarinnar í Læknablaðinu.

Læknablaðið hefur verið gefið út samfellt í tæpa öld og er á meðal elstu vísindarita á Íslandi. Ritstjórn hefur lagt mikla áherslu á að fylgja í hvívetna reglum alpjóðlegra læknatímarita um birtingu fræðigreina, ${ }^{2}$ ekki síst til að tryggja að innsendar fræðigreinar hljóti faglega og óhlutlæga umfjöllun sérfræðinga. Blaðið er í stöðugri próun og er pað von mín og annarra í ritstjórn að pessar nýju leiðbeiningar muni styrkja blaðið enn frekar í sessi og verði sem flestum hvatning til að senda fræðigreinar í blaðið.

1. Gudbjartsson T, Gunnarsdottir A, Sigurdsson E. Leiðbeiningar fyrir höfunda fræðilegs efnis í Læknablaðinu. Læknablaðið 2011; 97: 699-704.

2. www.icmje.org - nóvember 2011.

Developing the journal - new guidelines for authors of research articles 